\title{
Revista de Medicina, 1916: the medical science between students and professors
}

\author{
André Mota
}

\section{INTRODUCTION}

$\mathbf{I}^{\mathrm{n}}$

n the first decades of Brazilian republicanism, the medical journals began to have an effect both on the scientific activities and on the public positions their authors occupied. In São Paulo case, in particular, we can repeatedly find the names of the leading doctors active during that period, such as Luiz Pereira Barreto, Adolfo Lutz, Emílio Ribas, Arnaldo Vieira de Carvalho, Vital Brazil and Rubião Meira, all characters with privileged access to publishing in daily newspapers and specialized magazines ${ }^{1}$. For those responsible for this kind of specialized literature, "São Paulo medical press gains more and more prominence in the other cultural centers in Brazil and may God communicate to them the germ of that enthusiasm regarding work and progress that can be seen in the men and things from the great Southern State" (p.40)².

Such publications may be considered a constant at that time, and their diversity is an indication of the transformations in the press and in Medicine itself. One of them appeared with very peculiar characteristics, establishing a new dialog capable of turning it into the first centennial and constantly published student journal in Brazil: the Revista de Medicina (RM).
The journal, which emerged in the turbulent context of the early years of São Paulo School of Medicine and Surgery $^{3}$, comprised the interests of students with the scientific production of their Professors, which formed a space for different experiences Here we intend, through $\mathrm{RM}$, to understand the context of its emergence more deeply, tinted by the time of its creation, by the intentions that can be seen between its lines, by the sensitivity with which it must have touched its first readers. Between the pride and hope to see it reflected in the young lines of its students and in the production of medical and scientific knowledge of its Professors and technicians, we have one of the scientific pillars that shaped the School of Medicine as a locus for the national medical knowledge.

As a scientific exercise to make the present visible through the past, by that which was gradually left behind, but is a survival in the memory, history may recover some of these marks, from the most genuine and present to the most distant and elusive, fruit of the contemporary thinking about this production. In the case studied, regarding the first $\mathrm{RM}$ issue, we will approach certain guidelines with some themes and images.

Professor in Preventive Medicine Department of the University of São Paulo School of Medicine - FMUSP; Coordinator of the Carlos da Silva Lacaz History Museum - FMUSP.

Mailing address: Av. Dr. Arnaldo, 455 - 4th floor - Office 4306. ZIP Code: 01246-9032. São Paulo, SP. Brazil. Email: amota@museu. fm.usp.br 


\section{The context of the creation: the student turmoil}

When the São Paulo School of Surgery was founded in 1912 the student entrance examinations intended to form homogeneous classes with good performances. However, this regulatory requirement soon received new dimensions:

[...] because there was also the establishment of the possibility for holders of diplomas from the State Secondary Schools, the Normal High Schools, the official colleges as well as for applicants who presented certificates from the examining boards and the old Secondary Schools equivalent to the National Secondary School to waive such examinations. ${ }^{3}$ Nevertheless, the entrance examinations were applied between February 14 and 21, 1913, with 160 candidates enrolled and 72 candidates approved*.

The presence of women was applauded, since the medical class itself had previously pled their admission to higher education. Dr. Victor Godinho, for whom "women's rights should be equal or at least almost equal to men's," blamed the past history for the creation of barriers to women's emancipation, glorifying:

Lucretia, the faithful wife, and Cornelia, the fortunate mother, whose fortune was to reject the throne offered by Ptolemy in order to devote all of her solicitude to the education of her children, turning them into more obliging citizens in ancient Rome. But today, though all ladies are Lucretias and Cornelias, they can no longer cross the thresholds of imortality ${ }^{4}$.

Then, the first fruits from São Paulo School of Medicine were expected from this first group, formed by men and women. However, when faced with the real training and attitude of these students, Arnaldo Vieira de Carvalho complained to the Home Secretary: "if these obstacles mentioned to the smooth operation of the medical course were not enough, we could show you some other obstacles which deserve attention, copious amounts of attention"s.

In these terms, he was emphatic in referring to the poor quality of secondary education, from the training of students to the dubious presence of several private institutions selling fake diplomas, especially around capital. According to him, the students barely knew the four basic mathematical operations and had almost no command of the Portuguese language. The Home Secretary, Altino Arantes, after receiving the letter and the protests of the director of the School, told the State President, Rodrigues Alves:

[...] however, I do not have reasons to believe I have been too pessimistic by stating that most of the students enrolled are not prepared. A fact that resonated outrageously in society - the forgery of diplomas - allows me to think so. As you know, as a result of this incident, a totally depressing fact for our secondary school, I refused, as being of no value, the degrees of Bachelor in Sciences and Letters by certain educational establishments. This measure of wide scope came to hold in its mesh a certain number of candidates to enrollment who claimed to be holders of legitimate diplomas ${ }^{6}$.

With the authorization of Rodrigues Alves, a special examining board for those who claimed to be affected by the procedure was formed. From its results, Altino Arantes concluded: "Well, these Bachelors in Sciences and Letters were found in such bad scientific preparation conditions as any of the examined candidates who failed. The proof of this is due to the fact that none of them managed to overcome the obstacles to admission, though, I insist, the boards were benevolent"6.

They questioned, furthermore, the very intellectual orientation and the programs offered which, oriented towards the scholastic training of students, did not adequately value areas required for the medical course such as Chemistry, Physics and Natural Sciences. According to their evaluation, students educated in normal and secondary schools or in equivalent schools were seen as not fit, since they did not offer enough guarantees of scientific preparation to enroll in the School. The capital noted the immense gap between the dream of selecting the "best minds" so that São Paulo could give birth to the best physicians, and the reality of an Elite unprepared for the civilizational aspirations.

Yet, this dream continued to be nurtured. The

\footnotetext{
* "Enrollments started on February 26 and ended on March 11. 180 students enrolled, all of them with entrance examination of all grades, by the State Secondary School, 16; Science and Arts and Letters graduates, 9; Law graduates, 20; Science and Arts and Letters graduates by equivalent secondary schools, 103; graduates of the Normal School of the capital, 22; transferred from the Rio de Janeiro Faculty of Medicine, 8; and graduates from the Polytechnic School, 2" apud Guimarães ", p.13.
} 
system of grades and evaluations was established from the regulations of the Polytechnic School, brought by its director, Antonio Francisco de Paula Souza, from Switzerland, where he had studied. A greatest strictness throughout the evaluation process was the goal in order to ensure proper training to all the students in the School as well as the respectability resulting from this procedure.

On July $16^{\text {th }}, 17^{\text {th }}$ and $18^{\text {th }}$ the partial examinations, comprised of four annual tests on different subjects, were applied. The grades achieved would be added to the classification of the end-of-the-year assessments. According to the Faculty's Board of Directors, the results would have revealed very little study because, despite the benevolence of many Professors when it comes to correcting, the grades were low. On August $11^{\text {th }}, 12^{\text {th }}$ and $13^{\text {th }}$, the second partial assessments took place and, in the words of Dr. Arnaldo, a series of riots took over the corridors and classrooms due to the students that "being aware of the grades that they deserved in the tests presented for the second time decided, before knowing the judgment of the last partial examinations, to express their discontentment towards the Professors who did not grant good grades to bad tests"7.

For Ernesto Souza Campos, a student in the first class, other reasons moved the students against the test regime. Even though he defended the Faculty's conduct and disapproved of the actions that led to an institutional crisis, the student recalled:

[...] the two first Physics and Chemistry partial assessments were conducted irregularly. Students were concentrated in a small room of the Business School, where they could barely fit. In common stools and tiny desks, they compressed against each other, like swallows perched on a telephone cable. Any attempt at monitoring the tests was fruitless. Edmundo Xavier, a Professor experienced in dealing with students, retreated into a neighboring room. He left the youngsters to their trainer, a newly graduated young doctor, who could do nothing to maintain discipline $[\ldots]$ the result from this circumstance was that the vast majority of the class was ranked below the grade 5 where the highest grade was 20, that is, 2.5 in the current system, where the highest grade is $10^{8}$.

This evaluation system would have resulted in the uprising of many students, who criticized Professor Xavier and Dr. Arnaldo. For their part, they reaffirmed their purposes, deciding that the classes should return to normal. However, on August 14, Dr. Arnaldo reported that the students, "upon entering the class of Professors Bourrol and Brumpt, erupted in a commotion that had no major consequences because, according to a later testimony from students, one of the victims of the booing was foreign and it made those who were booing feel embarrassed". However, "the same did not happen to Dr. Edmundo Xavier who, being Brazilian, could naturally be offended with impunity by Brazilian students"'.

According to Campos, the "rebel students" might have been inflamed by the leaders of the Universidade de São Paulo School of Medicine, which, as opposed to the official School of Medicine, believed it was possible to ruin this school. Regardless of who the true organizers of these uprisings were, Dr. Arnaldo was forced to close doors for a few days due not only to the booing against Dr. Xavier, but also to the violence of the students who, turning to his private Clinic, vandalized it, threatening the Professor's freedom to come and go: "there was a time in which said Professor was in the Business School building, and he could not leave due to the threats of aggression"s.

While students criticized the assessment system, the beadles handed the Board of Directors a list with eleven names of people they considered responsible for disorders. It was a twofold difficulty: there were doubts regarding who was actually responsible for disorders and embarrassment in the face of the surname that many of those students bore*. The dilemma persisted because the students' strategy consisted of each accused person presenting four classmates who would swear he/she was innocent. In view of this, it was decided not to punish anyone and return to the normal pace of classes from the 23rd on.

As the classes restarted, the booing against Professors Brumpt and Xavier started again, which led an already stunned Board of Directors to close the School and to call the Congregation, which, on September $3^{\text {rd }}$, in

\footnotetext{
* They were: Francisco Antonio Dell'Ape, Afonso Mariano Fagundes Junior, Jovino Soares, Octavio Silveira da Motta, Arthur Costa Filho, Mario Florence Teixeira, J. de Toledo Mello, Antonio Leopoldino dos Passos Junior, Francisco de Paula Palmerio, Gaudencio Quadros Filho, J. Candido Pinto (Carvalho ${ }^{9}$ apud Guimarães ${ }^{7}$, p.863).
} 
accordance with Article 210 of the regulation, suspended for one year all the students present in the class in which there had been disturbances. 95 students were punished, from which 59 appealed to the Congregation. On the $16^{\text {th }}$, the results of the partial assessments resulted in new conflicts in class with Professor Xavier and 34 more suspensions; the students were prohibited to enter. At that point, some of them, considered by Dr. Arnaldo the "best of the School", those who had not taken part in the events, presented themselves to the Board of Directors to repudiate the acts occurred and to support the institution*.

The total number of enrolled students in 1913 was 180 , but only 70 remained: 58 failed the year due to absences and 52, due to indiscipline. In the final exams only 34 passed, while 36 failed. In his report, Arnaldo Vieira de Carvalho concludes his impressions in the face of the number of suspensions and subsequent failures in the inaugural year of the São Paulo School of Medicine and Surgery: "the students punished by the Board of Directors organized symbolic burials in which, giving wings to their troublemaker and hooligan instincts, broke plates in the Professors' offices and caused other disorders until they fell under police repression"”.

This outcome may have been the result of support not only from the Congregation but also from the Oswaldo Cruz Academic Center (Centro Acadêmico Oswaldo Cruz - CAOC), founded in mid-1913. Initially, this academic center was formed precisely by the students who opposed to the attitude of the Professors and the Board of Directors, and therefore were disconnected from the School and, consequently, from the CAOC. Those who remained there were exactly those who stood in favor of the institution ${ }^{* *}$. Thus, the CAOC earned the mission of collaborating with the Board of Directors and the school plans in order to make it more of an example of strength and power. This included welcoming the great personalities who visited the medical school. Among its records in the RM, the Center worthily celebrated the honorable visits "of the eminent scholar Dr. Oswaldo Cruz, the distinguished statesman Dr. Rodrigues Alves, the exalted poet Olavo Bilac and the honorable Professor Aloysio de Castro. Effusive greetings were addressed to all of them; such greetings were wrapped in spontaneous demonstrations of enthusiasm on the part of the scholars" $"$

Actions that could establish the CAOC as an academic body were also part of its initiatives: organizing its statute, designing its banner and finally leading an editorial project. Thus, Revista de Medicina was born. With a team directed by the president of the CAOC, Ernesto de Sousa Campos, a more experienced student, qualified in Engineering and responsible for some architectural projects in the medical and health fields, the RM had, as its first editor in chief: Jayme Candelária; Secretary-editor: Altino Antunes; reviewer editors: Flamínio Fávero and Antonio de Almeida Júnior; general writers: Ibrahim C. Madeira and I. Cardoso. Due to the conflicts recently experienced, RM was presented with the great challenge of producing a new spirit of institutional unity between students and Professors, and thus to achieve its more specific scientific goals; that is, to establish some of the medical and academic concerns of the institution through the studies of Professors and students.

\footnotetext{
* They were: Benedicto Oscar de Carvalho Franco, Benjamim Reis, J. Ferreira dos Santos, Odette dos Santos Nora, Jayme Candelaria, S. Comparato, Henrique Dante de Castro, Luiz Fortunato de Arruda Botelho, Antonio Furlan Junior, Flaminio Favero, S. dos Santos Bonfim, Austin Ribeiro Vilella, Ernesto de Souza Campos, Floriano Smith Bayma, Arnaldo Meira Cassinelli, Getulio M. Coelho de Castro, Edmundo Venturelli, J. Passos da Silva Cunha, Orlando Meirelles Pinto, Antonio Cyrino Filho, Herculano da Silva Macuco, Antonio Cerveira Gomes, Annibal Ortiz Patto, J. Verissimo de Oliveira, Raphael Fighera, Ernesto de Campos, Philemon Marcondes, J. Baptista Brasiliano, Messias Fonseca, Pedro Basile, S. Osorio de Azevedo Antunes, J. Carlos Gomes, M. Vicente Euryster Lofiego, João Procopio, Gennarino Berardinelli and J. de Toledo Mello (Carvalho ${ }^{9}$ apud Guimarães ${ }^{7}$, p.869-70).

** President: Ernesto de Souza Campos, Vice-President: Synesio Rocha, 1st Secretary: Sebastião Antunes, 2nd Secretáry: D. Odette dos Santos Nora, 1st Treasurer: Benjamim Reis, 2nd Treasurer: J. Ferreira Santos, 1st Speaker: J. Passos Cunha, 2nd Speaker: Renato de Lacerda.
} 


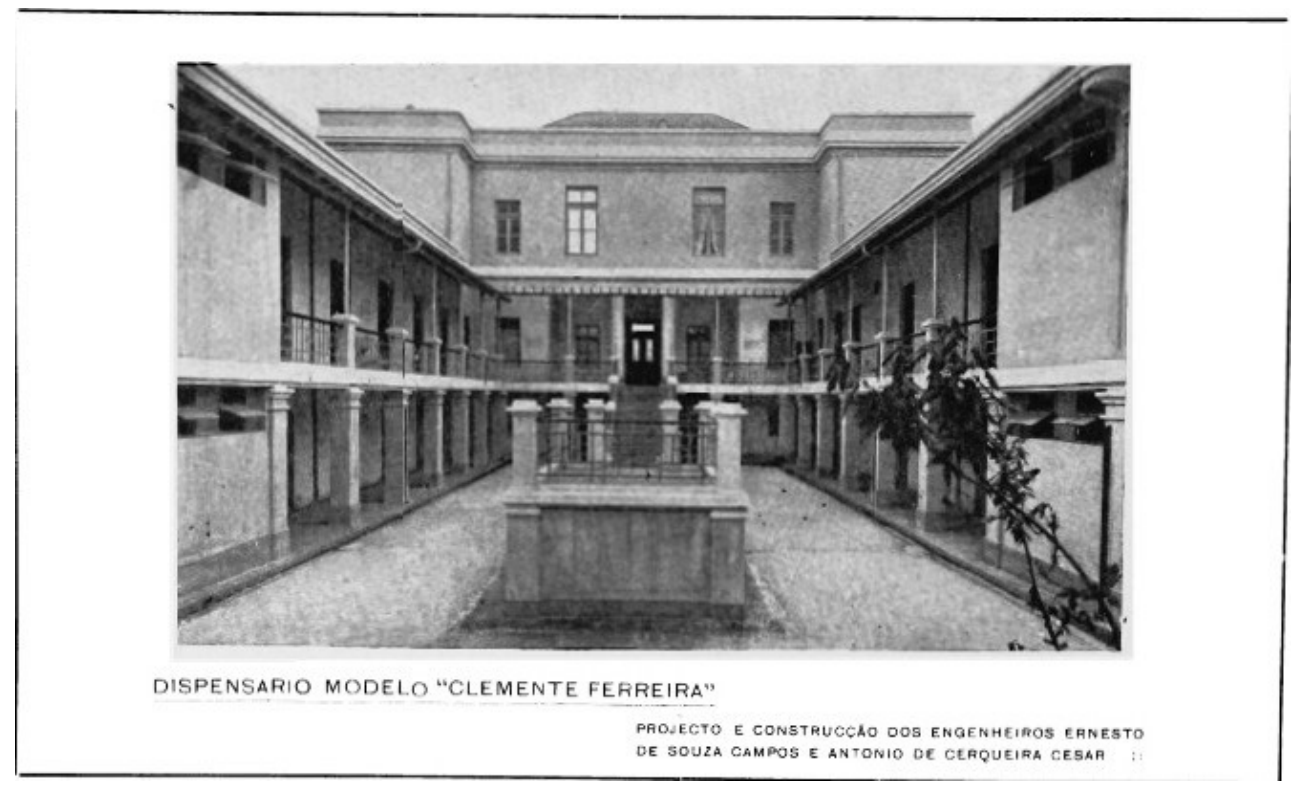

Figure 1. Project of Ernesto de Souza Campos presented in the first pages of Revista de Medicina, n. 1

The unifying strategy: the medical and scientific knowledge

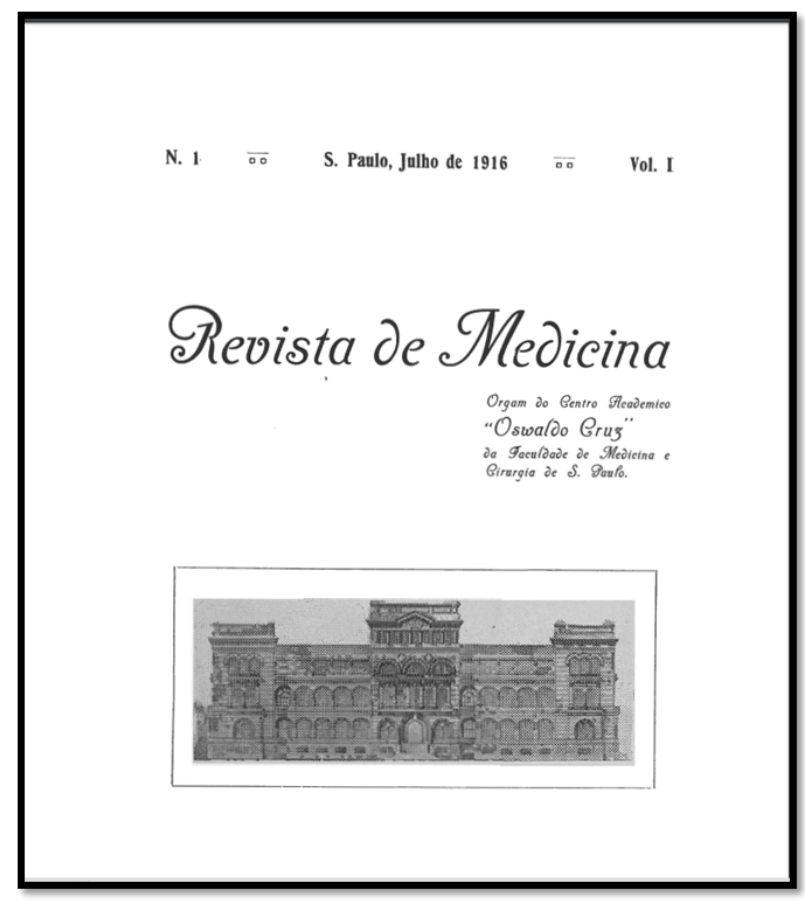

Figure 2. Revista de Medicina, São Paulo, v. 1, n. 1

Approaching this editorial interest, we find the Professors represented in different ways. Initially, with a tribute to Léo Lopes de Oliveira, Natural History trainer, a doctor who was considered to be a promising scholar but died in 1913, the São Paulo School of Medicine and Surgery's first year of operation.

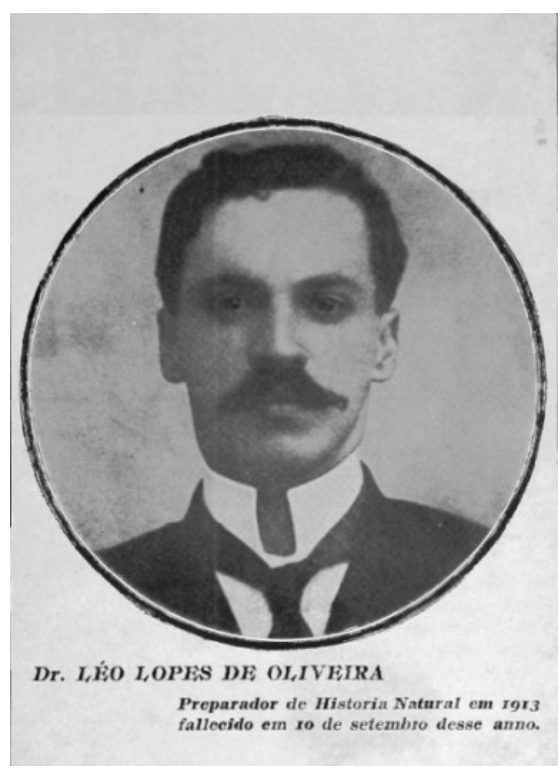

Figure 3. Revista de Medicina, São Paulo, v.1, n. 1, 1916

Soon after that, the physiology Professor Ovídio Pires de Campos, a Professor who was loved by the students and was entirely trusted by Arnaldo Vieira de Carvalho, alluded to the importance of transferring the Academic Center to the responsibility of those who supported and helped build the name of the School of Medicine. His words sought, clearly and directly, to appease spirits and restore the friendly relationship between students and Professors:

It is true that the appearance of 'Revista de Medicina' does not convey the sweet taste of originality: among us in Brazil and also abroad publications blossom and 
fruit; publications that, like RM, are bodies of student corporations. It does not reveal, either, that in the ranks of our medical press, already so bright on its own, there are large blank spaces to be filled. Its mission is narrower: housing in its columns the works of Professors and students of São Paulo School of Medicine and Surgery - generated in the stillness and silence of the offices and laboratories - it shall reflect the very life of this School, from which it will turn to be like a spreading or extravasation. Those who took to this attempt were well warned: Medicine, as an art, could not be an orphan to the scientific and doctrinal truths. 'If it is true - as expressed Torres Homem, one of the luminaries of Brazilian Medicine - that theory without the experience is worth too little when it comes to the art of healing, it must also be confessed that a routine and empirical practice, devoid of criterion and without solid basis on which to sustain, is extremely harmful to humanity and is often followed by fatal consequences ${ }^{10}$.

The strategy to contribute to the studied and produced medical science was, undoubtedly, an unprecedented point for the RM, unknown then to interested readers from São Paulo. Since then, a mixture of what was learned in the classroom and in the laboratories with the technologies considered as the most innovative ones started to translate part of the School of Medicine's life until the present day. If we wish to seek the origin of this idea, we will find it in the very first issue of the RM.

In his article "How the breeding ground should rationally be prepared", the young Chemistry trainer Geraldo de Paula Souza put on display one of medicine's central points under the impact of the Flexner Report*: its laboratorial dimension. This study introduced the precepts of Bacteriology, still in its early days, demonstrating that the organisms developed and proliferated in certain conditions of temperature, light, humidity, pressure and feeding, and these factors varied among different beings. For this it brought as bibliographical references German laboratory studies with the aiming at proving also that the medical and scientific production had an internationalist and cosmopolitan nature, enabling, through the exchange of knowledge acquired, greater agility and better control of the frameworks of interest of such production ${ }^{11}$.

Another point discussed in this first issue is the importance of clinical examination, unequivocal appreciation of the hospital as a teaching site, a theme that would be central for Arnaldo Vieira de Carvalho in his search for a teaching hospital. Combined with this was the fact that the so-called tropical diseases directly affected the immigrants who sought work in newly opened coffeegrowing areas in the countryside of São Paulo, especially in the Northwest. It is in this context that we can follow the description of the parasitology coach Aristides G. Guimarães, with the work "Moléstia de Raynaud de origem palúdica (Raynaud's disease as originated by Malaria)"13:

L. T., Syrian, 20 years old, single, worker, from Bauru. Previous illnesses - he does not mention any. Contracted Malaria in Bauru, one month ago; is feverish every day. The patient was in a semi-comatose, feverish state, therefore he did not complain of pain in the toes of both feet. He presented coated tongue, liver painful on palpation and with increased volume -2 fingers below the coastal margin. Enlarged spleen 3 fingers below the costal margin and painful on pressure. There was nothing important in the other organs. The blood test revealed numerous rings of the tropical disease. We gave the patient an injection of 914 and he improved considerably, coming out of the sub-comatose state he was in. A few days later we could verify, due to the pains, that the patient had purplish-colored toes. He also had erupting blisters. The gangrene continued to march upwards and took over the lower thirds of both legs ${ }^{12}$.

For RM, the presence of Rubião Meira in its first issue was, in addition to its content, a vote of legitimacy. A distinguished practitioner and medical clinic Professor in the School of Medicine, Rubião Meira was one of São Paulo's most prestigious doctors and was responsible, even before the foundation of the medical school, for qualification courses at São Paulo Santa Casa de Misericórdia. In his study "Conseqüências futuras da terapêutica (Future consequences of therapeutics)"14, published in RM, he reports that "three drugs whose effects

\footnotetext{
* In 1910 the book Medical Education in the United States and Canada was published. This document is known as the Flexner Report due to the fact that it was prepared by Abraham Flexner, an American social researcher and educator of Jewish descent, commissioned by the Carnegie Foundation. Adopted by the Rockefeller Foundation's General Education Board, the report in question triggered profound reform in the medical education in North America, extending to other fields of knowledge, consolidated the curricular architecture that currently prevails in the University network of industrialized countries.
} 
can already be pointed out via observation and are already stated as real, beneficial, useful and indispensable to the greatness of the future race. They are: sodium iodide and Neosalvarsan, in intravenous injections and emetine in hypodermic injections"13. It is interesting to notice how the clinical experience of the office merged with the drug indications, connecting scientific knowledge to experience, that is, the foundations that formed what was considered to be the good liberal physician, a type of professional starting to gain ground in São Paulo ${ }^{15}$. An excerpt from an article is enlightening:

The sodium iodide, by the Klemperer method, in intravenous injections is nowadays the treatment that is becoming a classic for rheumatism, both acute and chronic, in all its varieties. Its solution may be of 10 per 100 , as the author tells, or 20 per 100 , as many use, and I include myself among them. A daily injection of 10 or 20 cubic centimeters of this solution is administered, and truly extraordinary cases of healing have been observed, not only because a certain and safe result is obtained but also because it is definitive and permanent. Many practitioners use larger doses, that is, administer injections of 20 and 30 grams of iodide per day with short intervals of 3 to 4 days. I prefer - and so I have been doing in my office - the daily renewed smaller doses. The cases of healing I have been observing are countless (p.44) ${ }^{14}$.

If trainers and Professors had their reserved space, disclosing their studies and fields of interest, the students also presented topics that were taught and discussed in the classroom. This was the case of the then fourth year student Flamínio Fávero, who, in the article "Aortic Insufficiency (means for its diagnosis)" available in the clinic for its diagnosis are many, we believe it is quite right to gather some of them in the few following lines, carefully picked during the wise propaedeutic lessons of our Faculty"15. Dividing them in the inspection, palpation, percussion and auscultation subtopics, Fávero described each of them and, in the last topic-instrumental exploration - he presented an innovation in medical technology: the imaging examinations through the following instruments:

(1) X-Rays - With the X-rays, we see the enlarged left ventricle, mainly in its longitudinal diameter. The tip of the heart presents a globular aspect, is rounded and goes downwards. (2) Electrocardiography - Through the Einthoven method, we can see the descent of the accident $\mathrm{S}$ in the electrocardiogram curve. This accident corresponds to the contractility of both ventricles. (3)
Sphygmography $\mathrm{X}$ - the route of the Corrigan pulse, anacrotic pulse, reveals the sharp ascension line, straight and long, due to the myocardium's higher force of contraction ${ }^{16}$.

By reading the students' studies we also followed how certain diseases were considered to be central for their clinical importance and due to being immensely spread in society. This was the case of Syphilis and its forms of identification and treatment. In "Clinical value of Wassermann Serum Reaction"17, the student Altino Antunes ${ }^{17}$ sought to show the debate around this type of diagnosis:

I do not wish, nor is it my intention to convince you that the Wassermann reaction is infallible, because if I tried to I would not proceed with loyalty since I do not think so myself; I also do not intend to tell you that the Wassermann reaction lacks value and that it is alchemy dressed in modern outfits, because if I said so, I would not be telling the truth; I want just to show you what its real value is and what indications we can expect from it ${ }^{17}$.

His article makes it clear that such serology depends on the conditions of the organism, reproducing a framework which during the first five days "after the primary accident", shows the reaction with negative results, and on the subsequent days until the thirtieth, the range from 3 to $20 \%$ positive results.

Finally, in the article "Luta vital (Vital Fight)", the student Messias da Fonseca ${ }^{18}$ sought Darwinists notes in Biology "in order to face the bleak truth of natural selection in which 'only the strongest succeed'. "Thus, they have three formidable weapons: resistance (to resist), mimicry (to pretend), and symbiosis (to ally)". Even though they are of biological nature, identifying insects and plants, the issues raised in this study would a few years later be the relevant in the medical field to the understanding of the human body itself. In this sense, eugenics would also be conceived as a medical term and incorporated into the conforming specialties of the profession. The medical corporation had a decisive role in the discussion on how eugenics could or could not be applied, understood as a "scientific technology" to achieve racially stronger and healthier beings. From obstetric studies to the actions of surgeons, from sanitary practices experiments implemented by Psychiatrists, all of them engaged in the Darwinist-based eugenics precepts. 


\section{FINAL CONSIDERATIONS}

If the medical journals have been produced since the Nineteenth Century with several intentions, from a sanitary agenda to the presentation of cutting-edge medical technologies, RM was founded with all these nuances, reflecting a certain tradition of the international and national medical press. It was no exception in this aspect, as Ovídio Pires de Campos had observed. However, the unprecedentedness that would mark its centennial life would be the creation of a space that brought students and Professors together around medical topics and where

\section{REFERENCES}

1. Silva MRB. Revistas médicas paulistas e a nova realidade republicana. In: Mota A, Marinho MGSMC, organizadores. Práticas médicas e de saúde nos municípios paulistas: a história e suas interfaces. São Paulo: Faculdade de Medicina-USP/CD.G Casa de Soluções; 2011. (Coleção Medicina, Saúde e História). Available from: http://www2. fm.usp.br/gdc/docs/museu_78_vol_1.pdf.

2. Editorial. Gazeta Clínica (São Paulo). 1920;18(4):41-5.

3. Mota A. Tropeços da medicina bandeirante: medicina paulista de 1892-1920. São Paulo: Edusp; 2005.

4. Nadai E. Ideologia do progresso e ensino superior (São Paulo 1891-1934). São Paulo: Loyola; 1987.

5. Godinho V. A mulher nas escolas superiores. Rev Med (São Paulo). 1906;10:202-9.

6. Almeida Filho N. Reconhecer Flexner: inquérito sobre produção de mitos na educação médica no Brasil contemporâneo. Cad Saúde Pública (Rio de Janeiro). 2010;26(12):2234-49. doi: http://dx.doi.org/10.1590/ S0102-311X2010001200003.

7. Guimarães AP. Arnaldo Vieira de Carvalho: biografia e crítica. São Paulo: FMUSP; 1967.

8. Relatório apresentado ao Dr. Francisco de Paula Rodrigues Alves (Presidente do Estado de São Paulo) pelo Secretario do Interior Altino Arantes, anno 1912. São Paulo: Typ. Brazil de Rothschild \& Comp; 1914.

9. Carvalho AV. Ofício n. 118, 17 set. 1913. (Mimeo) experience and learning could coexist.

Even though it is known, this remarkable feature often goes unnoticed among its readers, but eventually indicated the most diverse studies and Professors, and also that the collaboration of the students also pointed trails of future medical knowledge and names that would someday stand out as Physicians, Professors or Directors of the Universidade de São Paulo School of Medicine. We only had to touch its first issue to understand why Revista de Medicina is one of the most important journals in the Brazilian medical history.

10. Campos ES. História da Universidade de São Paulo: comemoração do IV Centenário da Fundação da Cidade de São Paulo. São Paulo: USP; 1954.

11. Campos OP. Revista de Medicina. Rev Med. 1916;1(1):34. Available from: http://revistas.usp.br/revistadc/article/ view/56465/59536.

12. Bynum WF. Science and the practice of medicine in the nineteenth century. Cambridge: Cambridge University Press; 1994.

13. Guimarães AG. Moléstia de Raynaud de origem paludica. Rev Med. 1916;1(1):21-3. Available from: http://revistas. usp.br/revistadc/article/view/56467/59537.

14. Meira R. Consequencias futuras da therapeutica. Rev Med. 1916;1(1):43-6. Available from: http://revistas.usp.br/ revistadc/article/view/56471/59541.

15. Schraiber LB. O médico e seu trabalho: limites de liberdade. São Paulo: Hucitec; 1993.

16. Fávero F. Clinica propedêutica. Insufficiencia aortica (meios para o seu diagnostico). Rev Med. 1916;1(1):25-9. Available from: evistas.usp.br/revistadc/article/view/56468/59538.

17. Antunes A. Valor clinico da sôro-reacção de Wassermann. Rev Med. 1916;1(1):30-6. Available from: http://revistas. usp.br/revistadc/article/view/56469/59539.

18. Fonseca MF. Lucta vital. Rev Med. 1916;1(1):37-42. Available from: http://revistas.usp.br/revistadc/article/ view/56470/59540. 